\title{
Persepsi dan Motivasi Mahasiswa Universitas Al Azhar Indonesia terhadap Pembelajaran Mata Kuliah Universitas
}

\author{
Zirmansyah \\ Program Studi Pendidikan Anak Usia Dini, Fakultas Psikologi Pendidikan, \\ Universitas Al Azhar Indonesia, Jl. Sisingamangaraja, Jakarta 12110 \\ Penulis untuk Korespondensi/E-mail: zirmansyah@uai.ac.id
}

\begin{abstract}
Abstrak - Penelitian ini bertujuan untuk mendapatkan data tentang persepsi dan motivasi mahasiswa terhadap pembelajaran mata kuliah umum (MKU) dosen, untuk menjawab pertanyaan, apakah terdapat pengaruh persepsi dan motivasi mahasiswa tentang pembelajaran yang dilakukan dosen MKU terhadap hasil belajar. Sampel sebanyak 155 mahasiswa diambil dari populasi mahasiswa peserta MKU, dengan teknik sampling multistage random sampling. Hasil analisis data menyimpulkan terdapat pengaruh yang signifikan persepsi dan motivasi mahasiswa terhadap pembelajaran MKU dosen dengan hasil belajar nya, dengan perkataan lain semakin baik dan kuat persepsi dan motivasi mahasiswa akan pembelajaran yang dilakukan dosen MKU, semakin baik daya serap mahasiswa. Diyakini melalui pembelajaran MKU di harapkan misi ke tiga UAI, dapat tercapai, karena itu perlu terus dilakukan peningkatan kompetensi dosen MKU.
\end{abstract}

Abstract - The aim of this study was to obtain data on the perception and motivation of students towards the study of lecturer's general subjects (MKU), to answer the question, whether there is an effect of student perception and motivation towards the study of lecturer's general subjects (MKU) on learning outcomes. We tested 155 students drawn from the population of students participating in MKU, using multistage random sampling technique. The results of data analysis concludes that there is significant effect of student perception and motivation towards the study of lecturer's general subject (MKU) on learning outcomes, or in other words, the better and stronger the perception and motivation of students are, the better the students's absorbtion. Through MKU, expected the third mission of UAI can be achieved. That's why, the competence of MKU's lecturers need to be improved, permanently.

Keywords - Perception, Motivation , Study of lecturer's general subjects.

\section{PENDAHULUAN}

B erbeda dengan perguruan tinggi swasta lainnya, universitas Al Azhar Indonesia didirikan berdasarkan desakan jamaah Al Azhar, yang beranggapan bahwa perlu ada perguruan tinggi Islam yang berkualitas dan berbeda dengan perguruan tinggi Islam lainnya yang sudah ada. Berdasarkan alasan tersebut, maka ketika pemerintah mengeluarkan izin berdiri (UAI) Universitas Al Azhar Indonesia maka visi-misi, program dan tujuan pendidikan UAI berbeda dengan visi-misi, program dan tujuan pendidikan perguruaan tinggi pada umumnya.

Tahun 2011, dirumuskan visi, misi, program dan tujuan pendidikan UAI yang baru, dan khusus pada misi ketiga UAI, yang selanjutnya dijabarkan ke dalam Rencana Strategis tahun 2011-2015, misi ketiga adalah menumbuh-kembangkan nilai-nilai universal Islam dalam pembentukan karakter [1]. Misi yang diturunkan dari Visi yang berbunyi "menjadi universitas terkemuka dalam membentuk manusia unggul dan bermartabat yang memiliki kemampuan intelektual, berlandaskan nilai-nilai spiritual, moral dan etika Islami”.

Berdasarkan visi dan misinya Universitas $\mathrm{Al}$ Azhar Indonesia selain bertekad untuk menjadi universitas terkemuka, dalam membentuk manusia 
unggul, melalui penyediaan sistem pendidikan yang selalu menyesuaikan dengan kemajuan dan perkembangan ilmu penge tahuan serta tuntutan masyarakat. Penekanan sebagai mana terdapat dalam misi ketiga UAI adalah agar para lulusannnya tidak hanya cerdas secara intelektual tetapi juga cerdas secara emosional serta memiliki karakter dan perilaku terpuji sehingga dapat dijadikan teladan di manapun ia berada. Semuanya itu tentu berlandaskan pada nilai-nilai universal Islam.

Dalam upaya menghasilkan lulusan sebagai mana dinyatakan di atas, yakni lulusan yang memiliki karakter dan prilaku terpuji ber landaskan nilainilai universal Islam, maka setiap mahasiswa UAI wajib mengikuti delapan mata kuliah umum dan mata kuliah universitas. Mata kuliah umum yang wajib diikuti setiap mahasiswa UAI adalah sebagaimana yang terdapat dalam Peraturan Pemerintah nomor 12 tahun 2012, tentang sisitem Pendidikan Tinggi di Indonesia, yakni; (1) Pendidikan Pancasila dan Kewarganegaraan, (2) Bahasa Indonesia, (3) Bahasa Inggris dan (4) Statistika serta empat mata kuliah universitas yakni; (1) Agama, (2) Integrasi Ilmu dan NilaiNilai Islam, (3) Kepemimpinan dan Kewirausahaan, serta (4) Teknologi Informasi dan Komunikasi Terapan.

Tahun 2010, agar tujuan pemberian delapan mata kuliah tersebut tercapai secara efektif serta pelaksanaannya berjalan secara efisien, maka Rektor membentuk dua pusat, yakni Pusat Mata Kuliah Universitas dan Pengawasan Etika (PMKUPE) dan Pusat Kajian dan Penerapan Nilai-Nilai Islam (PKNI). PMKUPE bertugas agar pembelajaran MKU berlangsung secara efektif dan efisien serta mencapai sasaran sedangkan PKNI bertugas agar setiap mata kuliah tersebut diintegrasikan dengan nilai-nilai universal Islam.

Upaya lain yang dilaksanakan agar tujuan pembelajaran mata kuliah umum dan universitas tercapai adalah adanya koordinator untuk setiap mata kuliah tersebut, yang bertugas menyatukan satuan acara pembel ajaran (SAP). Dengan SAP yang sama diharapkan bahan ajar baik itu materi pertatap muka serta tugas-tugas yang diberikan kepada setiap mahasiswa, metode dan teknik evaluasi yang digunakan dosen adalah sama. Selain adanya penyamaan SAP, oleh universitas untuk mengetahui apakah tujuan pembelajaran delapan mata kuliah umum dan universitas tersebut terserap dengan baik, karena diajarkan oleh dosen yang terseleksi, maka saat akan diadakannya Ujian Tengah Semester dilakukan umpan balik dari mahasiswa bagi dosen berupa pemberian kuesioner kepada setiap dosen untuk menilai kualitas pembelajar an dosen. Kuesioner tersebut terdiri dari 12 butir pertanyaan dan pernyataan dengan lima rentang. Hasil kuesioner mahasiswa tersebut selanjutnya dianalisis oleh Biro Administrasi Akademik dan hasil análisis yang berupa skor selanjutnya diberikan kepada para koordinator MKU agar diinformasikan kepada para dosen di bawah koordinasinya. Semua ini dilakukan agar tujuan pendidikan UAI terutama pembentukan karakter dan prilaku terpuji berlandaskan nilai-nilai universal Islam benarbenar tercapai.

Permasalahannya adalah berdasarkan data kehadiran mahasiswa dalam mengikuti per kuliahan MKU tersebut ternyata ada mata kuliah yang partisipasi dan kehadiran mahasiswa sangat tinggi, dan sebaliknya terdapat mata kuliah yang partisipasi dan kehadiran mahasiswa sangat rendah. Bahkan dalam pelaksanaan ujian akhir semester ganjil tahun akademik 2012-2013 beberapa hari yang lalu, ada mata kuliah universitas yang ujiannya dibatalkan oleh dosen pengampunya karena mahasiswa seperti memboikot dan tidak mau ada ujian. Beragam alasan dan persepsi mahasiswa kenapa mereka tidak mau ujian, ada yang menyatakan meraka belum siap, ada yang menyatakan soalnya tidak sesuai dengan materi yang diberikan, bahkan ada mahasiswa yang menganggap mata kuliah tersebut tidak perlu diujikan karena tidak penting dan tidak mendukung dengan core competency yang mereka tempuh di UAI atau tidak terkait dengan kompetensi yang dibutuhkan ketika mereka melamar pekerjaan. Permasalahan pembelajaran MKU ternyata tidak hanya berasal dari para mahasiswa. Permasalahan juga muncul karena dosen, di mana saat ujian akhir semester akan berlangsung dosen tidak muncul dan soal ujian pun belum ada sehingga panita UAS terpaksa membatalkan ujian dan tentunya ini menimbulkan keributan dan protes dari mahasiswa yang berujung pada menculnya persepsi negatif mahasiswa terhadap perkuliahan MKU.

Berdasarkan wawancara dengan panitia Ujian Akhir Semester ternyata setiap tahun terjadi beragam permasalahan terkait pelaksa- naan UAS MKU. Semua permasalahan ini pada gilirannya menyebabkan mahasiswa sepertinya ogah-ogahan 
mengikuti perkuliahan MKU, apakah itu mata kuliah umum maupun mata kuliah universitas.

Untuk menemukan jawaban terhadap permasalahan pembelajaran MKU sebagai mana dinyatakan di atas dirasa perlu dilakukan suatu penelitian untuk menjawab pertanyaan-perta nyaan di atas. Penelitian yang lebih menekankan pada persepsi dan motivasi mahasiswa tentang pembelajaran MKU dan mengikuti perkuliahan MKU.

\section{Identifikasi Masalah}

Beragam permasalahan dan pertanyaan yang muncul dan dapat diindikasikan terkait dengan pelaksanaan perkuliahan MKU, yang perlu ditemukan jawabannya dalam penelitian ini. Secara lebih rinci permasalahan di atas dapat dirinci menjadi berbagai pertanyaan dan permasalahan sebagai berikut :

1. Bagaimana persepsi mahasiswa terhadap perkuliahan MKU?

2. Bagaimana persepsi mahasiswa terhadap kesiapan, dan sikap para dosen yang membina dan mengajar MKU?

3. Bagaimana motivasi mahasiswa untuk mengikuti perkuliahan MKU?

4. Bagaimaan daya serap mahasiswa terhadap MKU?

5. Apakah terdapat perbedaan daya serap mahasiswa terhadap perkuliahan MKU?

6. Bagaimana penilaian mahasiswa terhadap kesiapan dosen dalam mengajar MKU?

7. Bagaimana penilaian mahasiswa terhadap pembelajaran dosen?

8. Faktor-faktor apa saja yang menyebabkan mahasiswa termotivasi dan tidak termotivasi untuk mengikuti perkuliahan MKU?

9. Apakah terdapat perbedaan motivasi maha siswa untuk mengikuti perkuliahan MKU? Jika ada MKU apa yang motivasi mahasiswa paling kuat untuk mengikuti perkuliahan MKU?

10. Bagaimana persepsi mahasiswa terhadap penilaian yang dilakukan oleh dosen MKU?

\section{Pembatasan Masalah}

Berdasarkan identifikasi masalah diketahui bahwa banyak permasalahan yang muncul dari pembelajaran mata kuliah umum universitas. Permasalahan tersebut dapat berasal dari dosen, berupa kesiapan dan kualitas pembelajaran yang dilakukannya, dapat juga berasal dari mahasiswa karena persepsi dan motivasinya belajar MKU, karena sebagian besar MKU tersebut sudah pernah dipelajari baik saat mereka dijenjang pendidikan menengah maupun saat mereka di jenjang pendidikan dasar, sehingga jika dosen tidak dapat menyajikan pembelajaran yang menantang atau kurang dapat menimbulkan ketertarikan mahasiswa, maka tujuan pembel ajaran MKU tidak akan tercapai. Agar penelitian ini betul-betul dapat menjawab permasalahan secara mendalam dan utuh, maka perlu ada pembatasan terhadap masalah penelitian.

\section{Rumusan Masalah}

Rumusan masalah penelitian ini:

1. Bagaimana persepsi mahasiswa terhadap perkuliahan MKU?

2. Bagaimana motivasi mahasiswa untuk mengikuti perkuliahan MKU?

3. Bagaimana daya serap mahasiswa terhadap perkuliahan MKU?

4. Apakah terdapat pengaruh persepsi dan motivasi mahasiswa akan pembelajaran yang dilakukan dosen MKU terhadap daya serap mahasiswa?

\section{Kegunaan Penelitian}

Hasil penelitian ini diharapkan memberi kan manfaat dan berguna bagi:

1. Pimpinan Universitas khususnya Rektor dan Wakil Rektor Bidang Akademik, Promosi dan Sumber Daya Manusia dan Perpustakaan (APSP) agar mendapat kan data yang valid dan dapat dipercaya tentang kualitas pembelajaran MKU serta ketercapaian tujuan diberikannya MKU bagi setiap mahasiswa UAI. Terutama pencapaian misi ketiga UAI.

2. Pimpinan Fakultas dan Prodi, bagi P3EK dan PKNI data hasil penelitian akan menjadi masukan tentang gambaran kesesuaian antara kurikulum dalam hal ini adalah SAP MKU dengan tujuan pendidikan UAI. Apakah dosen MKU betul-betul melaksanakan semua hal yang terdapat dalam SAP. Bagi para koordinator MKU melalui penelitian ini dapat diketahui apakah dosen-dosen di bawah koordinasinya mengajar sebagaimana yang diinginkan oleh SAP yang telah disusun secara bersama,

3. Bagi BPMU UAI data hasil penelitian ini dapat menjadi salah satu bahan evaluasi akan kualitas pembelajaran UAI, 


\section{KAJIAN TEORI}

\section{Pengertian tentang Persepsi}

Secara sederhana persepsi dapat diartikan sebagai proses mengetahui atau mengenali objek dan kejadian dengan bantuan indera. Persepsi dalam arti umum adalah pandangan seseorang terhadap sesuatu yang akan membuat respon bagaimana dan dengan apa seseorang akan bertindak. Kotler menjelaskan persepsi sebagai proses bagaimana seseorang menyeleksi, mengatur dan menginterpretasikan masukan-masukan informasi untuk menciptakan gambaran keseluruhan yang berarti [2].

Mangkunegara sebagaimana yang dikutip Arindita, menyatakan persepsi adalah proses pemberian makna atau arti terhadap lingkungan [3]. Dalam hal ini persepsi terkaiat dengan penafsiran akan obyek, penerimaan akan stimulus (Input), pengorganisasian terhadap stimulus, dan penafsiran stimulus yang terorgani sasikan dan pada akhirnya berkaiatan atau mempengaruhi perilaku dan sikap. Persepsi diartikan sebagai proses dimana individu mengorgani sasikan dan menafsir kan pola stimulus dalam lingkungan [4]. Definisi lain menyebutkan bahwa persepsi adalah kemampuan membeda-bedakan, memfokuskan, mengelompokkan, terhadap suatu objek rangsang. Dalam proses pengelompokan dan membedakan ini persepsi melibatkan proses interpretasi berdasarkan peng alaman akan suatu objek dan atau peristiwa.

Persepsi juga dapat berarti sebagai hasil analisis seseorang terhadap hal-hal di sekelilingnya dengan kesan-kesan atau konsep yang sudah ada, dan selanjutnya berdasarkan hasil analisis ia mengenali hal-hal tersebut.

Dari definisi di atas dapat ditarik kesimpulan bahwa persepsi adalah proses mental yang melibatkan proses pengindraan dan berpikir, membedakan, mengelompokan, mengenali terhadap suatu objek untuk kemudian di nilai dan di ambil kesimpulan terhadap objek tersebut dan disimpan di dalam memori ingatan.

Persepsi membutuhkan adanya objek atau stimulus yang diindera oleh alat indera dengan perantaraan syaraf sensorik, kemudian diterus kan ke otak sebagai pusat kesadaran, selanjut nya di dalam otak terjadilah suatu proses psikologis yaitu pemaknaan hingga pada akhirnya individu dapat mengalami persepsi. Karena itu secara psikologi, persepsi diartikan sebagai salah satu perangkat psikologis yang menandai kemampuan seseorang untuk mengenal dan memaknai sesuatu objek yang ada di lingkungannya.

Proses pemaknaan yang bersifat psikologis sangat dipengaruhi oleh pengalaman, pendidikan dan lingkungan sosial secara umum. Karenanya tidak mengheran kan jika seringkali terjadi perbedaan pemahaman sebagai akibat oleh ada nya perbedaan persepsi antara dua orang terhadap objek yang sama. Persepsi tidak sekedar pengenalan atau pemahaman tetapi juga evaluasi bahkan persepsi juga bersifat inferensi terhadap suatu objek [5].

Persepsi adalah suatu kesan terhadap suatu obyek yang diperoleh melalui proses penginderaan, pengorganisasian, dan interpretasi terhadap obyek oleh individu, sehingga merupakan suatu yang berarti dan merupakan aktivitas yang terintegrasi pada individu tersebut [6]. Persepsi dimulai dengan proses penyerapan suatu objek atau penerimaan gambaran dan kesan suatu objek melalui panca indera dan pengorganisisi annya disertai interpretasi (penafsiran) sehingga objek tersebut bermakna bagi individu.

Persepsi seseorang bisa salah bahkan sangat berbeda dari persepsi orang lain. Kekeliruan atau perbedaan persepsi ini dapat memunculkan bermacam implikasi dalam hubungan antar manusia. Demikian juga dengan pembelajaran MKU meskipun sudah di upayakan penyatuan isi, materi, tugas-tugas yang diberikan, metode mengajar dosen, karena setiap dosen memiliki karakter dan kekhasan masing-masing, serta para mahasiswa yang menerima pembelajaran pun berasal dari beragam latar belakang social dan budaya serta lingkungan yang berbeda maka pastilah persepsi mereka baik dalam menerima pembelajaran maupun dalam cara mereka merespon perkuliahan juga berbeda.

\section{Proses Persepsi}

Alport menjelaskan proses persepsi merupakan suatu proses kognitif yang dipengaruhi oleh pengalaman, wawasan dan pengetahuan individu [7]. Pengalaman dan proses belajar akan memberikan bentuk, struktur dan format akan objek yang tertangkap oleh panca indera, sedangkan pengetahuan dan wawasan akan memberikan makna terhadap objek yang diterima individu yang pada gilirannya individu akan berperan dalam menentukan respondan jawaban 
yang berupa sikap dan tingkah laku individu terhadap objek. Walgito menyatakan terjadinya persepsi terdiri atas empat tahapan sebagai berikut: (1) Pertama, tahap yang dikenal dengan nama proses kealaman atau proses fisik, merupakan proses ditangkapnya suatu stimulus oleh alat indera manusia. (2) Kedua, tahap yang dikenal sebagai proses fisiologis, merupakan proses di teruskannya stimulus yang diterima oleh resep tor (alat indera) melalui saraf-saraf sensoris. (3) Ketiga, merupakan tahap yang dikenal dengan nama proses psikologik, merupakan proses timbulnya kesadaran individu tentang stimulus yang diterima reseptor, dan (4) Keempat, merupakan hasil yang diperoleh dari proses persepsi yaitu berupa tanggapan dan perilaku [6].

Rahman menyatakan empat hal terkait dengan proses persepsi yakni; (1) perhatian yang selektif. Individu setiap saat menerima beragam stimulus atau rangsangan dari lingkungan di mana ia berada. Rangsangan yang beragam dan banyak tersebut ternyata tidak semua direspon atau ditanggapi. Individu cenderung hanya memusatkan perhatian pada rangsangan tertentu saja, sehingga stimulus lain tidak akan diamati atau direspon. (2) karak teristik stimulus [8].

Arindita yang mengutip Newcomb menyatakan terdapat tiga sifat yang menyertai proses persepsi, yakni; (a) Menetap, dimana individu mempersepsikan seseorang sebagai orang itu sendiri walaupun perilaku yang ditampilkan berbeda-beda, (b) Selektif, persepsi dipengaruhi oleh keadaan psikologis si perseptor. Dalam arti bahwa banyaknya informasi dalam waktu yang bersamaan dan keterbatasan kemampuan perseptor dalam mengelola dan menyerap informasi tersebut, sehingga hanya informasi tertentu saja yang diterima dan diserap, dan (c) Proses organisasi yang selektif, di mana beberapa kumpulan informasi yang sama dapat disusun ke dalam polapola menurut cara yang berbeda-beda [3]. Hal ini sejalan dengan beberapa temuan penelitian yang menyimpulkan bahwa proses persepsi juga dipengaruhi oleh pengalaman belajar dari masa lalu, harapan dan preferensi [9].

Osgood menyatakan ada tiga dimensi dasar yang terkait dengan persepsi, yakni evaluasi atau penilaian (baik-buruk), potensi (kuat-lemah), dan aktivitas (aktif-pasif). Di mana penilaian merupakan dimensi utama yang mendasari persepsi, disamping potensi dan aktivitas [10].

\section{Sifat Persepsi}

Terjadinya persepsi dimulai dengan ditangkapnya suatu stimulus oleh panca indera, sedangkan pancaindera antar individu yang satu berbeda dengan yang pancaindera individu lain, perbedaan tersebut baik dalam hal ketajaman maupun dan normalitasnya. Selain itu stimulus dan pengalaman-pengalaman setiap individupun berbeda-beda, sehingga persepsi itu bersifat subjektif, dan berbeda-beda persepsi antar individu, meskipun stimulus, benda atau peristiwa yang dipersepsinya sama.

Newcomb menyatakan terdapat beberapa sifat yang menyertai proses persepsi yaitu; (a) konstansi (menetap), di mana setiap individu mempersepsikan suatu stimulus meskipun berubah-ubah, atau berbeda-beda, individu akan mempersepsikan stimulus itu tetap, (b) selektif, bahwa tidak semua objek yang diterima dalam waktu yang sama akan dipersepsi, namun individu akan memilih tergantung keadaan psikologis individu. Misalnya objek mana yang menarik, menyenangkan, berguna, kesesuaiannya dengan tingkat kemampuan individu dan sebagainya, dan (c) bahwa objek-objek persepsi yang berupa informasi -informasi yang sama, dapat diorganisir, ditafsirkan dan dinilai secara berbeda oleh orang yang berbeda, maupun orang yang sama [11].

\section{Pengertian Motivasi}

Motivasi merupakan keinginan, hasrat, dan sekaligus tenaga penggerak yang berasal dari dalam diri manusia untuk melakukan sesuatu. Pendapat lain mengatakan bahwa motivasi merupakan suatu kondisi fisiologis dan psikologis yang terdapat dalam diri manusia yang mengatur tindakannya dengan cara tertentu [12]. Oleh karena itu, motivasi terbentuk karena adanya kebutuhan atau need yang tidak terpenuhi, sehingga mengakibatkan seseorang mengalami ketidakseimbangan dan untuk mengurangi tekanan tersebut mereka melakukan usaha agar keseimbangan tercapai kembali [13].

Motivasi juga diartikan sebagai harapan seseorang untuk mendapatkan kepuasan dalam menyelesaikan tugas yang sulit dan menantang. Motivasi dibedakan menjadi dua macam, yaitu: (1) motivasi intrinstik yang menggambarkan keinginan berprestasi dengan melakukan tindakan karena adanya dorongan dari dalam dirinya, dan (2) motivasi esktrinstik sebagai keinginan untuk berprestasi karena upaya untuk menghindari dari hukuman [14]. 
Ciri-ciri seseorang yang memiliki termotivasi cenderung menyukai tugas dengan tantangan, lebih tertarik pada tugas-tugas yang penuh kompetisi, bersedia menerima umpan balik atas prestasinya, bersedia bertanggung jawab, siap mengorbankan waktu untuk menyelesaikan tugas yang sulit, dan bekerja untuk mencapai sesuatu yang lebih dari orang lain. Pengertian lain tentang motivasi adalah apa yang dinyatakan oleh McDonald, motivasi sebagai suatu keadaan internal yang menggerakkan, mengatur, mengarahkan, dan mempertahankan tingkah laku [15]. Sedangkan Thomas dan Brophy, menyatakan motivasi adalah kecenderungan organisma untuk melakukan suatu, sikap, atau perilaku yang dipengaruhi oleh kebutuhan dan diarahkan kepada tujuan tertentu yang telah direncanakan [16].

Timbulnya motivasi dalam diri seseorang di sebabkan berbagai faktor, seperti adanya kebutu han akan sesuatu hal, keinginan terhadap sesuatu, ingin tahu, dan kesenangan. McDonald, menyatakan motivasi seperti itu disebut motivasi intrinsik, sedangkan sesuatu yang berada di luar diri sese orang yang membuat orang itu melakukan kegiatan dinamakan motivasi ekstrinsik. Suatu

kegiatan yang timbul karena motivasi intrinsik maka mengandung penghayatan dan dorongan yang berkaitan secara mutlak dengan kegiatan yang akan dilakukan itu. Misalnya, seorang maha siswa kuliah JK3, karena ingin mengetahui selukbeluk berkenaan dengan kepemimpinan dan kewira usahaan karena ia ingin menjadi seorang yang betul-betul profesional dalam usaha. Agar ia mengerti cara memimpin dan berwirausaha yang benar maka satu-satunya jalan yang harus ia tempuh ialah mengikuti perkuliahan JK3.

Dalam perkuliahan kedua jenis motivasi di atas amat penting. Tetapi motivasi yang bersifat intrinsik biasanya mempunyai daya penggerak yang besar. Bilamana seorang mahasiswa melihat dengan jelas hubungan tujuan atau motif perbuatan (kuliah) nya itu dengan suatu sistem nilai dan tugas-tugas mata kuliah JK3, maka ia akan serius dan fokus serta tabah menghadapi berbagai kesulitan yang timbul, rintangan yang ada, dan situasi yang kurang menyenangkan dalam perkuliahan JK3. Karena itu sebabnya motivasi diakui sebagai aspek penting dalam kegiatan pembelajaran.

Fungsi motivasi seperti dikatakan oleh McCleland ada tiga: (a) memberi tenaga dan menupang tingkah laku, (b) memberi arah dan mengatur tingkah laku, (c) menentukan tingkah laku [13]. Ini berarti motivasi memberi daya bagi seseorang untuk melakukan kegiatan guna mencapai tujuan yang diinginkan.

McCleland, menyatakan bahwa orang yang memiliki motivasi kuat dalam perkuliahan sangat bersemangat, melakukan sesuatu dengan baik, lebih baik dari pada yang pernah dilakukan sebelumnya [13]. Orang yang memiliki motivasi tinggi, bila disajikan tugas-tugas yang kompleks merasa tertantang untuk sehera menyelesaikannya dengan benar. Meskipun demikian tidak berarti bahwa orang yang motivasi kuat akan berbuat lebih baik pada setiap keadaan. Orang yang tinggi motivasinya hanya berbuat lebih baik bila suatu prestasi dimungkinkan ia gapai. Ia mencari situasi yang memungkinkan ia dapat berprestasi, dan apabila ia dapat mencapai prestasi yang ia inginkan maka ia akan puas, dan kepuasan tersebut akan mendorongnya untuk ber prestasi kembali.

Perbedaan antara mahasiswa yang memiliki motivasi tinggi dan yang memiliki motivasi rendah akan tampak dari cara mereka melakukan perkuliahan dan mendekati masalah. mahasiswa yang memiliki motivasi tinggi akan menyelesaikan tugas-tugas perkuliahannya lebih baik dibandingkan dengan mahasiswa yang motivasi rendah. Mahasiswa yang memiliki motivasi tinggi kuliah dengan sangat giat, melakukan sesuatu dengan lebih baik dari yang pernah dilakukan. Dari uraian di atas dapat dikatakan motivasi merupakan proses pembang kitan gerak yang ada dalam diri seseorang untuk mencapai prestasi yang sebaik-baiknya lebih baik dari prestasi yang pernah dicapai.

\section{Metode dan Tujuan Pembelajaran MKU}

Pencapaian tujuan pembelajaran turut ditentu kan oleh ketepatan penggunaan metode pembel ajaran. Jika dosen dapat memilihkan metode dan teknik pembelajaran yang dapat mengoptimalkan aktifitas belajar mahasiswa, maka kualitas pem belajaran menjadi lebih optimal, artinya daya serap mahasiswa akan mata kuliah tersebut menjadi lebih baik. Sebagaimana yang dikatakan oleh Suparman, metode pembelajaran berfungsi sebagai cara dalam menyajikan, menguraikan, memberikan contoh, dan memberi latihan akan isi perkuliahan kepada mahasiswa untuk mencapai tujuan tertentu [17]. Dengan perkataan lain metode dan teknik pembelajaran yang dipilih oleh dosen dimaksudkan agar dapat memberikan, kemudahan, fasilitas, dan atau meningkatkan keterlibatan 
mahasiswa dalam mencapai tujuan-tujuan instruksional.

Banyak faktor yang mempengaruhi keterlibatan mahasiswa dalam pembelajaran terutama; (a) dosen, (b) mahasiswa, (c) materi kuliah, dan (d) metode. Faktor yang pertama adalah dosen. Dosen merupakan fasilitator bagi mahasiswanya. Sebagai seorang fasilitator, dosen seharusnya mempunyai pengetahuan yang luas. Dengan berbekal penge tahuannya, dosen diharapkan bisa meningkatkan keterlibatan mahasiswa dalam pembelajaran. Dosen dituntut untuk mengetahui, mengerti, menerapkan, meng analisis atau mengevaluasi segala sesuatu yang terjadi di ruang kuliah, dan dosen harus menciptakan situasi pembelajaran yang efektif dan efisien. Allen dan Valletta mengatakan dosen dikatakan berhasil apabila mahasiswa yang dia ajar terlibat dalam proses belajar mengajar [18].

Faktor yang kedua adalah mahasiswa. Kemp mengatakan bahwa mahasiswa merupakan pusat dari proses belajar mengajar [19]. Oleh karena itu mereka harus dilibatkan dalam setiap kegiatan kelas yang dimulai dari rencana dan pelaksanaan. Pada dasarnya mahasiswa mempunyai tiga kemampuan yaitu kognitif, afektif, dan psikomotorik. Ketiga aspek ini sangat ber pengaruh terhadap tingkat keterlibatan mahasiswa.

Faktor yang ketiga adalah materi per kuliahan. Faktor ini perlu diperhatikan untuk meningkatkan keterlibatan mahasiswa. Ada beberapa hal yang perlu diperhatikan berkaitan dengan materi per kuliahan seperti tingkat kesulitan, daya tarik, dan kelengkapan materi. Tingkat kesulitan materi per kuliahan dapat mempengaruhi tingkat keterlibatan mahasiswa. Materi yang terlalu sulit akan membuat mahasiswa mengalami kesulitan pemahaman, sedangkan materi yang terlalu mudah terkadang membuat mahasiswa malas dan bosan untuk mengerjakan.

Selain itu, daya tarik materi juga mempengaruhi tingkat keterlibatan mahasiswa dalam belajar. Materi yang menarik akan membantu mahasiswa merasa terkesan dan akhirnya mudah untuk memahaminya. Materi yang menarik akan mening katkan perhatian mahasiswa, sehingga mereka akan merasa senang dan merasa dirinya terlibat dalam kegiatan belajar-mengajar. Oleh karena itu, perlu adanya upaya-upaya yang dilakukan sehingga materi-materi pelajaran yang akan diberikan dapat meningkatkan keterlibatan mahasiswa.

Faktor keempat yang berpengaruh ter hadap tingkat keterlibatan mahasiswa adalah proses belajar-mengajar. Hal-hal yang ber hubungan terhadap proses belajar-mengajar adalah metode dan teknik mengajar. Penggunaan metode mengajar yang tepat akan berpengaruh terhadap tingkat keterlibatan mahasiswa.

Metode yang tepat dapat mendukung mahasiswa untuk merasa terlibat dalam proses belajarmengajar. Sebaliknya, metode yang tidak tepat akan menghambat keterlibtan mahasiswa. Oleh karena itu, upaya-upaya dalam memilih ketepatan metode yang dapat meningkatkan keterlibatan mahasiswa sangat diperlukan.

Selain metode mengajar, teknik mengajar juga berpengaruh terhadap upaya peningkatan keter libatan mahasiswa. Penggunaan teknik mengajar berhubungan langsung dengan kegiatan belajarmengajar di kelas. Apabila teknik yang digunakan sesuai dengan situasi dan kondisi, mahasiswa akan menjadi terlibat dalam proses belajar-mengajar. Sebaliknya, apabila teknik yang digunakan tidak sesuai, mahasiswa akan menjadi pasif dalam kegiatan belajar-mengajar, sehingga mereka men jadi tidak terlibat. Agar upaya-upaya untuk meningkatkan keterlibatan mahasiswa berhasil, maka teknik dalam mengajar pun juga perlu diperhatikan.

\section{Tujuan Pembelajaran MKU di UAI}

Dari delapan mata kuliah umum dan mata kuliah universitas, dapat dikelompokkan menjadi dua tujuan utama. Pertama, mata kuliah yang bertujuan untuk mempersiapkan mahasiswa UAI setelah lulus agar mudah terserap lapangan kerja, atau dapat berkompetisi dengan lulusan PTS lainnya. Mata kuliah kelompok ini disebut dengan mata kuliah alat, yang akan sangat dibutuhkan ketika seorang lulusan UAI mencari atau melamar pekerjaan terdiri atas empat mata kuliah, yakni; bahasa (Indonesia, Inggris dan Arab) serta Teknologi Informasi dan Komunikasi (TIK). Kedua, mata kuliah yang bertujuan menanam kan nilai-nilai atau etika dan atau mengembang kan karakter mulia mahasiswa juga terdiri atas empat mata kuliah yakni; Pancasila dan Pendidikan Kewarganegaraan, Agama Islam, Integrasi nilainilai dasar Islam, dan Kepemimpinan dan Kewirausahaan. 
Tujuan diberikannya dua kelompok mata kuliah sebagaimana tersebut di atas, adalah agar lulusan UAI selain memiliki kompetensi dan profesional dalam setiap bidang studi yang ditempuhnya di UAI, juga memiliki rasa kebangsaan dan cinta tanah air, demokratis dan berkeadaban, dan menjadi warga negara yang memiliki daya saing, berdisiplin dan berpartisi pasi aktif dalam membangun kehidupan dirinya dan masya rakat di mana ia berada berdasarkan nilai-nilai universal Islam yang diperolehnya ketika ia menempuh pendidikan di UAI.

Berdasarkan pendapat di atas dapat disimpul kan bahwa, pendidikan di UAI tujuan yang ingin dicapai, yaitu membentuk dan mengem bangkan semua potensi yang dimiliki individu agar bermanfaat baik untuk kepenting an hidupnya sebagai seorang individu, maupun sebagai warga negara dan warga masyarakat, di mana untuk mencapai tujuan tersebut, pendidikan di UAI perlu dilakukan secara sengaja dan terencana baik di dalam untuk memilih materi, strategi, kegiatan, dan teknik pembelajaran.

Agar pendidikan nilai-nilai universal Islam seperti dikemukakan di atas dapat diimplemen tasikan dan tercapai sesuai dengan misi yang terdapat dalam Renstra UAI maka diperlukan upaya yang terintegrasi dari semua pihak terutama dosen dan mahasiswa, diperlukan rasa bertanggung jawab terhadap pencapaian visi dan misi UAI.

Penanaman nilai-nilai universal Islami yang telah berlangsung selama ini di UAI sesungguh nya merupakan elaborasi dan berkaitan erat tujuan pendidikan serta tujuan didirikannya UAI. UAI didirikan sebagai antisipasi serta keinginan para jamaah Yayasan Pesantren Islam (YPI) Al Azhar akan lulusan pendidikan tinggi atau sumber daya manusia Indonesia yang selain memiliki kualitas dalam aspek kognitif juga memiliki kompetensi afektif dan psikmotorik yang didasari oleh nilainilai universal Islam.

\section{Kerangka Berfikir}

Berdasarkan uraian di atas diduga bahwa daya serap mahasiswa terhadap MKU dosen

dipengaruhi oleh pembelajaran yang dilakukan oleh dosen. Dalam arti jika mahasiswa mempersepsikan serta memiliki motivasi yang kuat terhadap pembelajaran MKU dosen, maka daya serap mereka terhadap nilai-nilai yang terdapat dalam MKU akan baik.

\section{Hipotesis penelitian}

Berdasarakan deskripsi teoretis dan kerangka berpikir di atas, maka hipotesis penelitian yaitu terdapat pengaruh persepsi, dan motivasi belajar MKU mahasiswa terhadap daya serap MKU.

\section{METODOLOGI PENELITIAN}

\section{Tujuan Penelitian}

Penelitian ini bertujuan untuk mendapatkan data serta informasi tentang persepsi dan motivasi mahasiswa Universitas Al Azhar Indonesia terhadap pembelajaran mata kuliah umum dan mata kuliah universitas, juga ingin mengetahui daya serap mahasiswa akan hasil belajar MKU. Secara lebih operasional penelitian ini bertujuan untuk memperoleh jawaban secara empirik akan:

1. Persepsi mahasiswa terhadap perkuliahan dosen MKU?

2. Motivasi mahasiswa dalam mengikuti perkuliahan MKU?

3. Daya serap mahasiswa terhadap perkuliahan MKU?

4. Apakah terdapat pengaruh persepsi dan motivasi mahasiswa akan pembelajaran yang dilakukan dosen MKU terhadap daya serap mahasiswa?

\section{Tempat dan Waktu Penelitian}

Penelitian dilaksanakan di UAI, tepatnya seluruh Fakultas dan program studi yang menawarkan MKU. Penelitian ini dilaksanakan dalam jangka waktu lima bulan, tepatnya mulai bulan Februari 2013 sampai dengan Agustus 2013.

\section{Metode Penelitian}

Penelitian ini menggunakan metode survey. Digunakannya metode survei, karena survey adalah jenis penelitian yang bertujuan untuk mendapatkan informasi tentang status gejala dan atau suatu fenomena yang terjadi pada saat penelitian dilaksanakan. Survei juga jenis penelitian yang bertujuan untuk pengumpulan informasi atau data yang digunakan dalam mengadakan penyelidikan hubungan antar variable atau untuk menguji hipotesis.

\section{Populasi}

Populasi target dalam penelitian ini adalah semua mahasiswa yang mengambil kedelapan MKU, pada semester genap tahun ajaran 2012-2013, yang berjumlah 628 mahasiswa, terdiri atas 10 program studi. 


\section{Teknik Sampling}

Sampling sebesar $25 \%$, dari populasi atau sebesar 155 mahasiswa diambil dengan menggunakan teknik sampling multistage random sampling. Sampel sebesar 155 orang mahasiswa tersebut hanya yang akan dikenakan atau diberi angket persepsi dan motivasi terhadap pembelajaran MKU dosen. Sedangkan untuk mendeskripsikan daya serap terhadap pembelajaran MKU maka diambil semua maha siswa peserta pembelajaran MKU dosen yang ikut mengumpulkan tugas, ikut UTS dan ikut UAS serta nilainya terdapat dalam SIA UAI berjumlah 628 orang mahasiswa atau sampling populasi.

Dengan cara ini diyakini sampel penelitian benarbenar refresentatif, baik dalam aspek responden maupun dalam aspek criteria yang lain sehingga data tentang persepsi dan motivasi mahasiswa mengikuti pembelajaran MKU dosen benar-benar refresentatif.

\section{Instrumen Penelitian}

Untuk mendapatkan data digunakan alat pengumpulan data yang berupa kuesioner dan angket, serta tes. Kuesioner digunakan untuk mendapatkan data tentang kualitas pembel ajaran dosen MKU, angket digunakan untuk menda patkan data tentang persepsi dan motivasi mahasiswa terhadap pembelajaran MKU dosen sedangkan tes digunakan untuk mendapatkan data tentang daya serap mahasiswa terhadap MKU. Akan tetapi data daya serap mahasiswa terhadap perkuliahan MKU berasal dari setiap dosen MKU, maka tes yang digunakan adalah tes yang disusun oleh para dosen MKU.

Penelitian ini melibatkan dua variable bebas dan satu variable terikat. Variable bebas adalah; (1) persepsi mahasiswa terhadap perkuliahan MKU dosen $\left(X_{1}\right)$, dan (2) motivasi mahasiswa mengikuti perkuliahan MKU $\left(\mathrm{X}_{2}\right)$, sedangkan variable terikatnya daya serap mhs terhadap pembelajaran MKU dosen (Y).

\section{Teknik Analisis Data}

Data hasil penelitian dianalisis dengan statistik deskriptif dan statistik inferensial. Dengan statistik deskriptif ingin diketahui karakteristik data hasil penelitian; (a) dispersi, meliputi; harga maksimum, minimum, rentang, simpangan baku, dan varians, (b) ukuran gejala memusat seperti; rata-rata, median, modus, (c) distribusi seperti; kurtosis, dan skewness, serta (d) penyajian data dalam bentuk distribusi frekuensi dan histogram. Dengan cara ini diharapkan diperoleh gambar an yang utuh akan karakteristik dari variabel yang diteliti. Sedangkan statisitk inferensial yang akan digunakan adalah korelasi sederhana.

\section{ANALISIS DATA HASIL PENELITIAN}

Terdapat empat rumusan masalah penelitian yang ingin ditemukan jawabannya dengan melakukan analisis data hasil penelitian. Sebelum semua rumusan masalah di atas dijawab, terlebih dahulu akan disajikan karaktersitik data hasil penelitian sebagai hasil pengumpulan data. Beberapa karakteristik data hasil penelitian antara lain adalah; (1) mata kuliah yang diteliti dan jumlah responden pengambil mata kuliah tersebut, (2) program studi yang mahasiswa yang mengambil MKU, (3) dosen-dosen pengampu MKU semester genap tahun ajaran 2012-2013, (4) nama dosen dan MKU yang diampu serta jumlah mahasiswa peserta MKU tersebut. Jawaban terhadap beberapa karakteristik data hasil penelitian disajikan ke dalam bentuk tabel 4.1 hingga tabel 4.5.

\section{Beberapa Karaktersitik data hasil penelitian MKU yang ditawarkan dalam semester genap tahun akademik 2012-2013.}

Tabel 4.1. Mata Kuliah Universitas yang diteliti dan jumlah mahasiswa pengambil

\begin{tabular}{llcc}
\hline No & Mata Kuliah & $\begin{array}{c}\text { Jumlah } \\
\text { Mahasiswa }\end{array}$ & $\%$ \\
\hline 1. & Agama Islam & 129 & 20.5 \\
\hline 2. & $\begin{array}{l}\text { Filsafat Ilmu \& } \\
\text { Nilai-Nilai } \\
\text { Islam }\end{array}$ & 191 & 30.4 \\
\hline 3. & JK3 & 108 & 17.2 \\
\hline 4. & PPKN & 200 & 31.8 \\
\hline & Total & 628 & 100.0 \\
\hline
\end{tabular}

Berdasarkan data sebagaimana yang terdapat dalam Tabel 4.1 terdapat empat MKU yang diteliti persepsi dan motivasi mahasiswa serta daya serap mahasiswa terhadap perkulihan MKU tersebut, yakni; (1) Agama islam, (2) Filsafat Ilmu dan Nilai-Nilai Islam, (3) Penumbuhan Jiwa Kepemimpinan dan Karakter Korporasi (JK3), serta (4) Pendidikan Pancasila dan 
Kewarganegaraan. dari keempat MKU tersebut MKU yang terbanyak mahasiswa pengambil MKU tersebut adalah PPKN sebanyak 200 orang mahasiswa atau $(31,8 \%)$, dan Filsafat Ilmu dan Nilai-Nilai Islam sebanyak 191 orang atau (30,4\%), sedangkan MKU dengan peserta paling sedikit adalah JK3 yang jumlah pesertanya 108 orang atau $17,2 \%$.

\section{Program studi dan jumlah mahasiswa peserta MKU}

Program studi dalam semester genap tahun akademik 2012-2013, yang memprogram ke empat MKU serta berapa jumlah mahasiswa program studi tersebut yang ikut mengambil MKU dapat dilihat dalam Tabel 4.2.

Tabel 4.2. Program studi dan jumlah mahasiswa peserta MKU

\begin{tabular}{|c|c|c|c|}
\hline No & Program Studi & Jumlah mhs & $\%$ \\
\hline 1. & Akuntansi & 122 & 19.4 \\
\hline 2. & Ekotek & 98 & 15.6 \\
\hline 3. & Manajemen & 70 & 11.1 \\
\hline 4. & PAUD & 55 & 8.8 \\
\hline 5. & Psikologi & 34 & 5.4 \\
\hline 6. & S_Arab & 73 & 11.6 \\
\hline 7. & S_Cina & 15 & 2.4 \\
\hline 8. & S_Inggris & 105 & 16.7 \\
\hline 9. & S_Jepang & 36 & 5.7 \\
\hline \multirow[t]{2}{*}{10.} & T_Informatika & 14 & 2.2 \\
\hline & Total & 628 & 100.0 \\
\hline
\end{tabular}

Dari Tabel 4.2 diketahui sepuluh program studi dari enam belas program studi yang ada di UAI pada semester genap tahun akademik 2012-2013, memprogram MKU. program studi yang mahasiswanya terbanyak mengambil MKU adalah Akuntansi sebanyak 122 orang atau 19,4\%, diikuti oleh Sastra Inggris sebanyak 105 orang atau $16,7 \%$, sedangkan program studi yang

mahasiswanya pada semester genap tahun akademik 2012-2013 paling sedikit mengikuti MKU adalah Teknik Informatika dan Sastra Cina masing-masing 14 orang dan 15 orang. Jumlah dosen pengampu MKU semester genap tahuan akademik 2012-2103, berjumlah 20 ang, dengan jumlah mahasiswa peserta 628 orang.

\section{Jawaban Rumusan Masalah Penelitian Rumusan masalah pertama}

Rumusan masalah pertama yang ingin ditemukan jawabannya adalah persepsi atau pendapat para mahasiswa peserta MKU terhadap perkuliahan MKU. selengkapnya rumusan masalah tersebut adalah: "Bagaimana persepsi mahasiswa terhadap perkuliahan MKU? ". Untuk menjawab pertanyaan di atas, maka dikumpulkan data dengan menggunakan angket tentang persepsi mahasiswa tentang pembelajar an MKU dosen, dengan angket ini akan diperoleh data tentang persepsi mahasiswa terhadap perkuliahan MKU dosen. Angket terdiri atas dua belas pernyataan dan atau pertanyaan, yang disusun menggunakan teori yang terdapat dalam kajian teori bab dua.

Angket disusun menggunakan skala model Likert, dengan rentang skor $1 \mathrm{~s} / \mathrm{d} 5$, untuk butir-butir yang positif, dan skor $5 \mathrm{~s} / \mathrm{d} 1$ untuk butir-butir negative. Ke lima opsi alternative jawaban terhadap angket adalah: Sangat Kurang Positif - Kurang Positif Sedang - Positif - Sangat Positif. Untuk menterjemahkan skor jawaban responden menggunakan pedoman pengelompokkan skor sebagaimana Tabel 4.3.

Tabel 4.3. Pedoman Pengelompokan Skor

\begin{tabular}{|c|c|c|c|}
\hline \multicolumn{2}{|c|}{$\begin{array}{c}\text { Persepsi Mhs } \\
\text { terhadap } \\
\text { pembelajaran MKU } \\
\text { dosen }\end{array}$} & \multicolumn{2}{|c|}{$\begin{array}{c}\text { Motivasi Mahasiswa } \\
\text { terhadap } \\
\text { pembelajaran MKU } \\
\text { dosen }\end{array}$} \\
\hline $\begin{array}{c}\text { Rentang } \\
\text { Skor }\end{array}$ & Sebutan & $\begin{array}{c}\text { Rentang } \\
\text { Skor }\end{array}$ & Sebutan \\
\hline $\begin{array}{c}1,00 \mathrm{~s} / \mathrm{d} \\
1,80\end{array}$ & $\begin{array}{l}\text { Sangat } \\
\text { Kurang } \\
\text { positip }\end{array}$ & $\begin{array}{c}1,00 \mathrm{~s} / \mathrm{d} \\
1,80\end{array}$ & $\begin{array}{l}\text { Sangat } \\
\text { Rendah }\end{array}$ \\
\hline $\begin{array}{c}1,81 \mathrm{~s} / \mathrm{d} \\
2,60\end{array}$ & $\begin{array}{l}\text { Kurang } \\
\text { positip }\end{array}$ & $\begin{array}{c}1,81 \mathrm{~s} / \mathrm{d} \\
2,60\end{array}$ & Rendah \\
\hline $\begin{array}{c}2,61 \mathrm{~s} / \mathrm{d} \\
3,40\end{array}$ & Sedang & $\begin{array}{c}2,61 \mathrm{~s} / \mathrm{d} \\
3,40\end{array}$ & Sedang \\
\hline $\begin{array}{c}3,41 \mathrm{~s} / \mathrm{d} \\
4,20\end{array}$ & Positip & $\begin{array}{c}3,41 \mathrm{~s} / \mathrm{d} \\
4,20\end{array}$ & Kuat \\
\hline $\begin{array}{c}4,21 \mathrm{~s} / \mathrm{d} \\
5,00\end{array}$ & $\begin{array}{l}\text { Sangat } \\
\text { Positip }\end{array}$ & $\begin{array}{c}4,21 \mathrm{~s} / \mathrm{d} \\
5,00\end{array}$ & $\begin{array}{c}\text { Sangat } \\
\text { Kuat }\end{array}$ \\
\hline
\end{tabular}


Selanjutnya skor hasil analisis jawaban mahasiswa terhadap angket persepsi mahasiswa terhadap pembelajaran MKU dosen hasil analisis data dengan menggunakan statistic deskriptif dibaca dengan menggunakan pedoman penskoran sebagaimana Tabel 4.3.

Bagaimana sebaran jawaban responden terhadap kuesioner tentang Persepsi mahasiswa terhadap pembelajaran MKU oleh Dosen dapat dilihat dari tabel 4.4. Sesuai dengan pedoman pengelompokkan skor dan sebutan sebagaimana terdapat dalam tabel-6, di atas tentang persepsi mahasiswa terhadap pembelajaran MKU dosen diketahui bahwa rerata skor tertinggi atau adalah untuk "Ketepatan Mata kuliah ini untuk menanamkan nilai-nilai universal Islam" sebesar 3,94. Ini berarti bahwa para mahasiswa peserta MKU (Agama Islam-JK3 dan PPKN) berpendapat dan menilai bahwa mata kuliah-mata kuliah tersebut sangat sesuai dan tepat digunakan untuk menamkan nilai-nilai universal Islam bagi mahasiswa peserta kuliah tersebut, atau dengan perkataan lain melalui mata kuliah-mata kuliah ini nilai-nilai universal Islam lebih mudah ditanamkan pada individu.

Berdasarkan data ini maka Pimpinan Universitas perlu serius membahas perkulihan MKU terkait dengan pencapaian Misi ke-3, UAI. Penilaian lain para mahasiswa peserta MKU yang positif terhadap pembelajaran MKU adalah pada aspek "kesiapan dosen dalam mengajar" dengan rerata skor 3,88, masuk dalam kategori "positif" ini berarti bahwa para mahasiswa peserta MKU menilai atau berpendapat bahwa para dosen MKU mengajar dengan persiapan yang baik.

Inferensi yang dapat diambil dari data di atas adalah jika dosen mengajar dengan persiapan yang baik, maka ketika saat pembel ajaran berlangsung dosen akan percaya diri, sehingga dosen dengan mudah menyampai kan bahan ajar dengan baik, dosen dapat menjawab pertanyaan para mahasiswa dengan baik, menjadikan mahasiswa puas-karena pertanyaan nya terjawab dengan baik.

Dari hasil analisis kuesioner persepsi mahasiswa terhadap pembalajran MKU, skor rerata terendah adalah untuk pernyataan "Mata kuliah ini dapat dipelajari sendiri" dan "Merasa rugi jika tidak mengikuti perkuliahan" masing-masing dengan rerata skor 3,39 dan 3,35, atau pada sebutan sedang, atau mahasiswa tidak begitu yakin jika diminta untuk belajar sendiri terkait dengan pengetahuan-pemahaman serta penanaman nilainilai Universal Islam. Selanjutnya berdasarkan skor rerata jawaban mahasiswa terhadap kuesioner persepsi mahasiswa tentang pembelajaran dosen MKU peserta MKU menilai atau memiliki persepsi bahwa pembelajaran dosen MKU adalah baik.

Tabel 4.4. Rerata skor persepsi mahasiswa terhadap pembelajaran MKU dosen

\begin{tabular}{llc}
\hline No & \multicolumn{1}{c}{ Pernyataan } & Mean \\
\hline 1. & $\begin{array}{l}\text { Kebermanfaatan mata kuliah ini } \\
\text { terhadap diri sendiri }\end{array}$ & 3.70 \\
\hline 2. & $\begin{array}{l}\text { Kegunaan mata kuliah dalam } \\
\text { kehidupan bermasyarakat }\end{array}$ & 3.77 \\
\hline 3. & $\begin{array}{l}\text { Materi yang disajikan sesuai } \\
\text { dengan yang diinginkan }\end{array}$ & 3.45 \\
\hline 4. & Kesiapan dosen dalam mengajar & 3.88 \\
\hline 5. & Semangat dosen dalam mengajar & 3.83 \\
\hline 6. & $\begin{array}{l}\text { Penjelasan dosen dalam } \\
\text { perkuliahan }\end{array}$ & 3.70 \\
\hline 7. & $\begin{array}{l}\text { Penjelasan dosen terhadap silabus } \\
\text { mata kuliah }\end{array}$ & 3.61 \\
\hline 8. & $\begin{array}{l}\text { Kompetensi dosen dalam } \\
\text { mengajar }\end{array}$ & 3.75 \\
\hline 9. & $\begin{array}{l}\text { Ketepatan MK ini untuk } \\
\text { menanam kan nilai-nilai } \\
\text { universal Islam }\end{array}$ & 3.94 \\
\hline 10. & $\begin{array}{l}\text { Anda merasa rugi jika tidak } \\
\text { mengikuti perkuliahan }\end{array}$ & 3.39 \\
\hline 11. & $\begin{array}{l}\text { Kualitas dosen tamu yang } \\
\text { dihadirkan untuk mengajar }\end{array}$ & 3.43 \\
\hline 12. & $\begin{array}{l}\text { Mata kuliah ini menambah } \\
\text { pengetahuan keagamaan }\end{array}$ & 3.74 \\
\hline
\end{tabular}

\section{Rumusan masalah nomor dua}

Permasalahan kedua yang ingin diketahui jawabannya adalah tentang: "Bagaimana motivasi mahasiswa untuk mengikuti perkuliahan MKU". Untuk mendapatkan jawaban terhadap pertanyaan adalah sebagaimana Tabel 4.5.

Sesuai dengan pedoman pengelompokkan skor dan sebutan secara keseluruhan tentang motivasi mahasiswa mengikuti perkuliahan dosen adalah 3,39. Skor 3,39 ini berada pada sebutan Sedang. Ini berarti motivasi mahasiswa mengikuti perkuliahan MKU dosen adalah sedang. 
Tabel 4.5 rerata skor motivasi mahasiswa

\begin{tabular}{|c|c|c|}
\hline No & Pernyataan & Mean \\
\hline 1. & $\begin{array}{l}\text { Konsentrasi anda dalam mengikuti } \\
\text { setiap perkuliahan MKU }\end{array}$ & 3.34 \\
\hline 2. & $\begin{array}{l}\text { Persiapan anda ketika akan } \\
\text { mengikuti perkuliahan MKU }\end{array}$ & 3.25 \\
\hline 3. & $\begin{array}{l}\text { Kemauan anda membaca literature } \\
\text { yang dianjurkan dosen MKU }\end{array}$ & 3.18 \\
\hline 4. & $\begin{array}{l}\text { Daya serap anda terhadap mata } \\
\text { kuliah MKU }\end{array}$ & 3.30 \\
\hline 5. & $\begin{array}{l}\text { Keseriusan anda dalam mengerjakan } \\
\text { tugas-tugas MKU }\end{array}$ & 3.52 \\
\hline 6. & $\begin{array}{l}\text { Gairah anda ketika akan mengikuti } \\
\text { perkuliahan MKU }\end{array}$ & 3.49 \\
\hline 7. & $\begin{array}{l}\text { Penilaian anda akan keseriusan } \\
\text { teman-teman anda mengikuti } \\
\text { perkuliahan MKU }\end{array}$ & 3.21 \\
\hline 8. & $\begin{array}{l}\text { Referensi terhadap Mata Kuliah ini } \\
\text { perlu ditambah }\end{array}$ & 3.34 \\
\hline 9. & $\begin{array}{l}\text { Penilaian anda terhadap kegairahan } \\
\text { teman-teman anda mengikuti } \\
\text { perkuliahan MKU }\end{array}$ & 3.32 \\
\hline 10. & $\begin{array}{l}\text { Kemauan anda mengumpulkan tugas } \\
\text { MKU tepat waktu }\end{array}$ & 3.72 \\
\hline 11. & $\begin{array}{l}\text { Kemauan anda mengikuti } \\
\text { perkuliahan sepenuh waktu }\end{array}$ & 3.71 \\
\hline
\end{tabular}

Skor rerata tertinggi motivasi mahasisa mengikuti perkuliahan dosen adalah 3,80 dan skor rerata terendah 3,18. Merujuk ke tabel 4.6, maka skor 3,80 , berada pada rentang sebutan "Sedang Kuat". Sedang artinya mahasiswa tersebut motivasinya untuk mengikuti perkuliahan MKU dosen adalah biasa-biasa saja, kuat artinya mahasiswa tersebut memiliki keinginan yang kuat untuk mengikuti perkuliahan MKU dosen.
Tabel 4.6. Skor rerata motivasi mahasiswa mengikuti perkuliahan MKU

\begin{tabular}{lll}
\hline No & \multicolumn{1}{c}{ Pernyataan } & Mean \\
\hline 1. & $\begin{array}{l}\text { Kemauan berpartisipasi agar } \\
\text { kuliah ini berjalan dengan baik }\end{array}$ & 3.80 \\
\hline 2. & $\begin{array}{l}\text { Gairah anda ketika akan } \\
\text { mengikuti perkuliahan MKU }\end{array}$ & 3.49 \\
\hline 3. & $\begin{array}{l}\text { Konsentrasi anda dalam } \\
\text { mengikuti setiap perkuliahan }\end{array}$ & 3.34 \\
\hline & MKU \\
\hline 4. & $\begin{array}{l}\text { Referensi terhadap Mata Kuliah } \\
\text { ini perlu ditambah }\end{array}$ & 3.34 \\
\hline 5. & $\begin{array}{l}\text { Penilaian anda terhadap } \\
\text { kegairahan teman-teman anda } \\
\text { mengikuti perkuliahan MKU }\end{array}$ & 3.32 \\
\hline 6. & $\begin{array}{l}\text { Daya serap anda terhadap mata } \\
\text { kuliah MKU }\end{array}$ & 3.30 \\
\hline 7. & $\begin{array}{l}\text { Persiapan anda ketika akan } \\
\text { mengikuti perkuliahan MKU }\end{array}$ & 3.25 \\
\hline 8. & $\begin{array}{l}\text { Penilaian anda akan keseriusan } \\
\text { teman-teman anda mengikuti } \\
\text { perkuliahan MKU }\end{array}$ & 3.21 \\
\hline 9. & $\begin{array}{l}\text { Kemauan anda membaca } \\
\text { literature yang dianjurkan dosen } \\
\text { MKU }\end{array}$ & 3.18 \\
\hline
\end{tabular}

\section{Rumusan masalah ketiga}

Rumusan masalah ketiga berbunyi: "Bagaimana daya serap mahasiswa terhadap perkuliahan MKU. Apakah terdapat perbedaan daya serap mahasiswa terhadap perkuliahan MKU, kalau ada perbedaan tersebut antar MKU apa saja"

Untuk mengetahui daya serap mahasiswa terhadap perkuliahan MKU dosen dapat dilihat dari nilai (skore) yang diperoleh mahasiswa. Setiap dosen yang mengajar di UAI di akhir perkuliahannya harus mengukur daya serap mahasiswa akan pembelajaran yang diberikan nya. Ukuran daya serap dalam hal ini adalah nilai (skor) yang diperoleh oleh para mahasiswa. Karena komponen nilai yang harus dilaporkan oleh setiap dosen terdiri atas nilai tugas-nilai UTS-nilai UAS serta nilai akhir yang merupakan penggabungan dari ketiga komponen nilai sebelumnya. 
Untuk mengetahui bagaimana nilai mahasiswa peserta perkuliahan MKU untuk semester genap tahun ajaran 2012-2013, dapat dilihat dalam tabel 4.7.

Tabel 4.7. Rata-rata skor nilai MKU mhs

\begin{tabular}{lcccc}
\hline \multirow{2}{*}{ Statistik } & \multicolumn{4}{c}{ Nilai } \\
\cline { 2 - 5 } & Tugas & UTS & UAS & Akhir \\
\hline Mean & 77.4 & 78.1 & 78.5 & 78.2 \\
\hline Median & 80.0 & 80.0 & 80.0 & 80.0 \\
\hline Mode & 80.0 & 80.0 & 80.0 & 80.0 \\
\hline $\begin{array}{l}\text { Std. } \\
\text { Deviasi }\end{array}$ & 8.40 & 9.59 & 11.29 & 7.50 \\
\hline Variance & 70.56 & 91.97 & 127.46 & 56.25 \\
\hline
\end{tabular}

Berdasarkan tabel-4.11, di atas diketahui bahwa terdapat peningkatan daya serap mahasiswa terhadap pembelajaran MKU dosen yang diindikasikan oleh semakin besarnya daya serap (nilai) UAS mahasiswa dibandingkan dengan daya serap (nilai) tugas maupun UTS, di mana rerata nilai UAS 78,5, lebih besar dibandingkan dengan nilai tugas dan UTS yang masing-masing $(77,4$ dan 78,1 ).

\section{Daya Serap Mahasiswa untuk setiap MKU}

Selanjutnya bagaimana daya serap mahasiswa untuk setiap mata kuliah MKU dapat dilihat dalam table $4.8,4.9$ dan 4.10 berikut ini.

\section{Mata Kuliah Agama Islam}

Tabel 4.8. Nilai data serap mhs terhadap Perkuliahan dosen

\begin{tabular}{lcc}
\hline No & Nilai UAS & Frekuensi \\
\hline 1. & $<70$ & 3 \\
\hline 2. & $71-75$ & 11 \\
\hline 3. & $76-80$ & 74 \\
\hline 4. & $81-85$ & 21 \\
\hline 5. & $86-90$ & 12 \\
\hline 6. & $91-95$ & 7 \\
\hline 7. & $>96$ & 1 \\
\hline & Jumlah & 129 \\
\hline
\end{tabular}

\section{Mata Kuliah Filsafat Ilmu dan Nilai-Nilai Islam}

Tabel 4.9. Nilai Filsafat Ilmu dan NilaiNilai Islam

\begin{tabular}{lcc}
\hline No & Nilai & Frekuensi \\
\hline 1. & $<55$ & 10 \\
\hline 2. & $56-60$ & 18 \\
\hline 3. & $61-65$ & 11 \\
\hline 4. & $66-70$ & 23 \\
\hline 5. & $71-75$ & 42 \\
\hline 6. & $76-80$ & 24 \\
\hline 7. & $81-85$ & 25 \\
\hline 8. & $86-90$ & 27 \\
\hline 9. & $91-95$ & 6 \\
\hline 10. & $>96$ & 5 \\
\hline & Jumlah & 191 \\
\hline
\end{tabular}

\section{Mata Kuliah JK3}

Tabel 4.10. Nilai JK3

\begin{tabular}{lcc}
\hline No & Nilai & Frekuensi \\
\hline 1. & $76-80$ & 43 \\
\hline 2. & $81-85$ & 35 \\
\hline 3. & $86-90$ & 26 \\
\hline 4. & $91-95$ & 4 \\
\hline & & 108 \\
\hline
\end{tabular}

Mata Kuliah PPKN

Tabel 4.11. Nilai PPKN

\begin{tabular}{lcc}
\hline No & Nilai & Frekuensi \\
\hline 1. & $<60$ & 2 \\
\hline 2. & $61-70$ & 16 \\
\hline 3. & $71-80$ & 89 \\
\hline 4. & $81-90$ & 91 \\
\hline 5. & $>91$ & 2 \\
\hline & Jumlah & 200 \\
\hline
\end{tabular}

Dari tabel-tabel tersebut diketahui bahwa terdapat perbedaan daya serap antara peserta kuliah MKU terhadp MKU yang mereka ikuti. Perbedaan tersebut dapat dilihat dari rentang nilai yang 
berbeda antar MKU maupun rerata, dan standar deviasi antar nilai-nilai tersebut.

\section{Rumusan masalah keempat}

Rumusan masalah keempat yang ingin ditemukan jawabannya adalah "Apakah terdapat pengaruh persepsi dan motivasi mahasiswa akan pembelajaran yang dilakukan dosen $M K U$ terhadap daya serap mahasiswa". Untuk mendapatkan jawaban terhadap pertanyaan di atas, maka data persepsi mahasiswa dan motivasi mahasiswa mengikuti pembelajaran MKU dosen dikorelasikan dengan nilai (daya serap) mahasiswa. Korelasi menggunankan statistic korelasi.

Hasil perhitungan korelasi antara persepsi mahasiswa terhadap pembelajaran MKU dosen dengan daya serap (nilai) mereka dihitung dengan menggunakan paket program SPPS, yang hasilnya adalah sebagaimana terdapat dalam tabel 4.12.

Tabel 4.12. Korelasi antar perpesi perkuliahan MKU dosen dengan daya serap MKU

\begin{tabular}{ccc}
\hline & & $\begin{array}{c}\text { Daya Serap } \\
\text { perkuliahan } \\
\text { MKU }\end{array}$ \\
\hline \multirow{2}{*}{$\begin{array}{c}\text { Perpesi } \\
\text { perkuliahan } \\
\text { MKU }\end{array}$} & $\begin{array}{c}\text { Pearson } \\
\text { Correlation }\end{array}$ & 0.593 \\
\cline { 2 - 3 } & Sig. (1-tailed) \\
\cline { 2 - 3 } & $\mathrm{N}$ & 155 \\
\hline
\end{tabular}

Berdasarkan tabel 4.15, di atas diketahui bahwa harga koefisien korelasi antara persepsi mahasiswa terhadap perkuliahan MKU dosen dengan daya serap mahasiswa terhadap MKU adalah sebesar 0,593, harga ini sangat signifikans (alpha $=0,01$ ). Dengan perkataan lain terdapat hubungan (pengaruh) yang signifikan persepsi mahasiswa terhadap pembelajaran MKU dosen dengan daya serap mahasiswa. Artinya semakin positif (baik) mahasiswa mempersepsikan dosen (kualitas dan kompetensi) maka semakin baik daya serap (nilai)nya, dan sebaliknya. Teryata hasil analisis statistic untuk motivasi dengan daya serap hasilnya sama dengan antara persepsi dengan daya serap yang juga sangat signifikan, sebagaimana terdapat dalam tabel 4.16, di bawah ini, yakni sebesar 0,412 , dan harga koefisien korelasi inipun signifikas (alpha $=0,01$ ).
Harga koefisien ini berarti terdapat hubungan (pengaruh) motivasi mahasiswa mengikuti perkuliahan MKU dosen dengan daya serapnya. Inferensi yang dapat diambil dari hasil analisis statistic ini adalah semakin kuat (tinggi) motivasi mahasiswa mengikuti perkuliahan MKU dosen maka semakin baik (besar) daya serapnya, dan sebaliknya.

Tabel 4.13. Korelasi antar motivasi mengikuti perkuliahan dengan daya serap MKU

\begin{tabular}{ccc}
\hline & & \multicolumn{1}{c}{$\begin{array}{c}\text { Daya Serap } \\
\text { terhadap MKU }\end{array}$} \\
\hline \multirow{2}{\text{Motivasi}}{$\begin{array}{c}\text { untuk } \\
\text { mengikuti } \\
\text { perkuliahan } \\
\text { MKU }\end{array}$} & $\begin{array}{c}\text { Pearson } \\
\text { Correlation }\end{array}$ & $.412^{*}$ \\
\cline { 2 - 3 } & Sig. (1-tailed) & .000 \\
\hline
\end{tabular}

Berdasarkan hasil analisis statistik di atas di mana ditemukan bahwa terdapat hubungan (pengaruh) antara persepsi dan motivasi mahasiswa terhadap pembelajaran MKU dosen dengan daya serapnya secara sendiri-sendiri, hal ini sejalan dengan berbagai teori belajar yang ada selama ini serta sejalan dengan bebrapa peneltiian terutama dalam bidang pendidikan bahwa persepsi yang positif akan menghasilkan keseriusan dan semangat belajar yang pada gilirannya akan meningkatkan hasil belajar.

Individu yang memiliki motivasi yang kuat (tinggi) untuk mencapai sesuatu cenderung akan berhasil, sebab dengan adanya motivasi tersebut ia akan terdorong dan bersemangat pangtang menyerah, ia akan mengerahkan segenap kemampuan yang dimilikinya untuk fokus terhadap apa yang diingin kannya untuk dicapai.

Demikian juga dalam pembelajaran MKU jika seorang memiliki persepsi yang positif dan memiliki motivasi yang kuat untuk belajar MKU maka ketika dosen menjelaskan mata kuliah tersebut ia akan memperhatikan dengan sungguhsungguh, ia akan mengerjakan semua tugas dengan sebaik-baiknya karena adanya keingintahuan lebih banyak terdahap MKU yang diikutinya. 


\section{KESIMPULAN, SARAN DAN REKOMENDASI}

\section{Kesimpulan}

\section{Kesimpulan deskriptif}

a. Secara keseluruhan para mahasiswa peserta MKU memiliki persepsi positif terhadap pembelajaran MKU dosen.

b. Secara keseluruhan motivasi mahasiswa mengikuti perkuliahan dosen adalah berada pada sebutan "Sedang dan Kuat".

c. Dosen MKU dari waktu ke waktu perkuliahan selalu memperbaiki dan meningkatkan kualitas pembelajaran nya sehingga daya serap mahasiswa menjadi semakin meningkat (baik).

d. Terdapat perbedaan daya serap antara peserta kuliah MKU terhadp MKU yang mereka ikuti. Perbedaan tersebut dapat dilihat dari rentang nilai yang berbeda antar MKU maupun rerata, dan standar deviasi antar nilai-nilai tersebut.

\section{Kesimpulan Inferensial}

a. Terdapat hubungan (pengaruh) yang signifikan persepsi mahasiswa terhadap pembelajaran MKU dosen dengan daya serap mahasiswa. Semakin positif (baik) mahasiswa memper sepsikan dosen (kualitas dan kompetensi) maka semakin baik daya serap (nilai)nya, dan sebaliknya.

b. Terdapat hubungan (pengaruh) motivasi mahasiswa mengikuti perkuliahan MKU dosen dengan daya serapnya. Semakin kuat (tinggi) motivasi mahasiswa mengikuti perkuliahan MKU dosen maka semakin baik (besar) daya serapnya, dan sebaliknya.

\section{Saran-Saran}

Agar pembelajaran berhasil maka perlu ditingkatkan persepsi dan motivasi mahasiswa dengan jalan:

1) Memperhatikan faktor-faktor internal maha siswa seperti; aspek fisiologis terutama perkembangan emosional mahasiswa serta perkembangan tahap berpikirnya. Mahasiswa karena sudah dewasa maka perkuliahan lebih banyak memberi kesempatan mereka untuk aktif dengan jalan pokok bahasan yang di bahas adalah permasalahan kontekstual, permasalah an yang dekat dengan kehidupan keseharian mereka.

2) Memperhatikan Faktor Eksternal, artinya dalam pembelajaran MKU dosen harus menggunakan berbagai alat yang sesuai dengan karaktersitik pokok bahasan MKU serta lingkungan mengkondisikan pembelajaran yang dapat meningkatkan perhatian mereka.

\section{Rekomendasi}

Temuan penelitian ini menyimpulkan bahwa terdapat pengaruh persepsi dan motivasi mahasiswa tentang pembelajar an MKU dosen, dengan daya serap MKU. Oleh karena itu maka pimpinan universitas serta pimpinan fakultas dan para koordinator MKU, Kepala Biro Akademik dan Kepala Pusat Integrasi Nilai dan Penerapan Islam perlu duduk bersama untuk terus meningkatkan dayaserap mahasiswa terhadap hasil belajar MKU, sebab pembelajaran MKU diharapkan misi ke tiga UAI, dapat tercapai. Karena yang di bahas baru daya serap (aspek kognitif), maka perlu penelitian lanjut terkait dengan aspek afektif dan psikomotorik.

\section{DAFTAR PUSTAKA}

[1] Renstra 2011-2015:5. Rencana Strategis Universitas Al Azhar Indonesia, tahun 2011-2015. Jakarta: LP2M UAI.

[2] Kotler, P. 2000. Attribution in Social Interaction. Morristown: General Learning Press.

[3] Arindita. 2002. Hubungan antara Persepsi Kualitas Pelayanan dengan Loyalitas. Skripsi. UMS. Solo.

[4] Atkinson, Rita.L. 1987. Pengantar Psikologi. Jakarta: Erlangga.

[5] Sarlito Wirawan Sarwono. 2000. Psikologi Remaja. Jakarta: Raja Grafindo Persada.

[6] Bimo Walgito. 2003. Psikologi sosial. Suatu pengantar. Yogyakarta; Fakultas Psikologi UGM.

[7] Mar'at. 1991. Sikap Manusia, Perubahan dan Pengukurannya, Jakarta, Ghallia Indonesia.

[8] Abdul Rahman,. 2004. Memahami Pikiran. Lembaga Studi Komunikasi Pembangunan Indonesia Jakarta.

[9] Bartol, Kathryn M and Bartol C. A. 1994. Satisfaction, performance, and percep tions. A SAGE Publications book

[10] Osgood, Stuart.1994. Attitudes and Opinions. New Jersey: Prentice Hall, Englewood Cliffs.

[11] Newcomb, Theodore M., Ralph H. Turner, and P. E. Converse. 2003. Social Psychology: The Study of Human Interaction.

[12] Crowl, Thomas K., Sally Kaminsky and David M Podell. 1997. Educational Psychology: Windows on Teaching. Brown \& Benchmark Publishers.

[13] McClelland, David C, et al. 1977. The Acievement Motive. New York:John Wiley \& Sons.,

[14] Huffman, Arnold, Hugh J and Daniel C Feldman. Organizational Behavior. New York: McGrawHill Book Company. 1997.

[15] Allen dan Valletta. 1972. Attitudes and Opinions. New Jersey: Prentice Hall, Englewood 
[16] Suparman, Atwi. 1993. Disain Instruksional Modern. Jakarta: Erlangga

[17] McDonald, Frederick. 2008. Educational Psychology. Belmont, California: Publishing Company, Inc.
[18] Kemp 1977. Motivation and Fantacy. Action and Society. New York: Prentice-Hall. Inc.

[19] Thomas L. and J. E. Brophy. 1998. Educational Psychology A Realistic Approach, New York: Longman. 